\title{
The Study of Grice Principle Application in Commercial Advertisements of Hamshahri and Jame Jam Newspapers
}

\author{
Dr. Foroogh Kazemi \\ Assistant Professor of Linguistics, Central Tehran Branch \\ Islamic Azad University, Tehran, Iran \\ f.kazemi86@yahoo.com \\ Anis Ebrahimi \\ M. A Student of Linguistics, Central Tehran Branch \\ Islamic Azad University, Tehran, Iran \\ ebrahimianiss@gmail.com
}

\begin{abstract}
Applying descriptive-analysis method, this study aims to examine functions of Gricean cooperative principle in two Iranian newspaper; "Hamshahri" and "Jame Jam". In this research fifty commercial advertisement in "Hamshahri" and "Jame Jam" newspapers have been accidently selected and analyzed in terms of Gricean cooperative principle. The result revealed that in both newspapers, the maxim of quality has suffered the highest flouting. This breaching always occurs to attract customers. So, this result can show the similarity between the newspapers in this way. Finding of this research indicate that despite the high value of Gricean cooperative principle, it's not been considered sufficiently and exactly. Even if these four maxis aren't observed in everyday communications, still the audience can figure the topic in question out and work it out i.e. not-observing the maxims of this principle, wouldn't leave the audience in darkness and would definitely bring the message home to the audience.
\end{abstract}

Keywords: Cooperative principle, Implicit, Commercial advertisement, Hamshahri Newspaper, Jame Jam Newspaper.

\section{INTRODUCTION}

Herbert Paul Grice was a British philosopher and although he was not a linguist, he used language as the subject of his studies which were conducted not only by making assumptions but also through employing scientific methodology. His prominent work is called Cooperative Principle, whose conversational maxims were firstly introduced in the paper Logic and Conversation delivered in Harvard University in 1967. The paper was published in the volume 3 of Syntax and Semantics in 1975. The final revised version of this theory was lastly published in the famous book Studies in the Way of Words in 1989. Studying a great deal of conversation led Grice to find that no conversation will be initiated or concluded satisfactorily between two individuals who have no cooperation or understanding. He argued that the speaking individuals have to understand each other so that they can engage in a conversation. In the second chapter of the book Studied in the Way of Words, Grice deliberately limits the cooperative principle to the conversations having one of the following features: 1) the participants have some common immediate aim, 2) the contribution of the participants is mutually dependent, and 3) there is some sort of understanding (mostly implicit) between the participants of a talk exchange which continues until the conversation conditions is stable unless the parties agree to stop the conversation.

Grice believes that our conversation is not a chain of irrelative statements, but rather it is based on cooperative efforts, in which the participants of a speech event are engaged in a kind of interaction. That is, they have not only common language and to some extent similar logical and epistemic points of view but also a common aim, which is holding an efficient and coherent conversation. Grice argues that discourse is an infinite set of linguistic and encyclopedic components and its degree of coherence depends on communication contexts (Grice, 1989: 53). What were introduced by Grice as cooperative maxims are indeed the conditions of a successful and reasonable conversation. Nonetheless, if we are 


\section{Dr. Foroogh Kazemi \& Anis Ebrahimi}

not able to express the cooperative principle as accurate as expressed by Grice, we are unintentionally aware of them. However, some individuals breach this principle in many talk exchanges. As we know, an effective communication is established by observing Grice's cooperative principle. Hence, any breach of this principle in conversation or a text may prevent us from a clear communication. In this research, we firstly introduce Grice' cooperative principle and secondly the compliance of two selected texts with this principle will be studied.

The research question is to find out how the Grice's Cooperative Principleis employed in two Iranian Hamshahri and Jame Jam Newspapers. Another question is if the breach of this principle in these two newspapers affects the understanding and comprehension of the readers of these newspapers. To answer these two research questions, the advertisements of these two newspapers are studied in terms of the application of Grice's cooperative principle. The data required for this research has been collected from Hamshahri and Jame Jam Newspapers published in Iran in Persian language using library method. For this purpose, 25 advertisements were selected from each newspaper (totally 50 ads) to study the application of Grice's Cooperative Principleand its maxims by these newspapers. At first, each advertisement was studied and analyzed separately by four maxims of Grice's cooperative principle. Thereafter, all 25 ads of each newspaper were put into a group to find out the number of their compliance or noncompliance from the maxims and determine the percent of compliance or breach of each ad from this principle.

\section{REVIEW OF LITERATURE}

Ahmadian and Mostoufi (2011) studied in a paper the elements of intent and fear in the characters of the play "Janitor (Seraydar in Persian)" in terms of Grice's Cooperative Principle. They argue that the analyses of the conversations of the characters based on Grice's Cooperative Principle reflect their mental mechanism, because their motive, fear, and weakness are presented through their dialogues which are the reflection of their behaviors. The playwright uses a style and language for the dialogues of the characters so that the readers or audience of the play can penetrate into the mind of the characters and understand their mental traits by analyzing their language based on Grice's Cooperative Principle. In a paper, Kheirabadi (2013) studied the role of flout of Grice's maxims in the new generation of Iranian jokes. He argues that flout of conversational cooperative maxims especially quality and relevance creates jokes. These jokes are coherent in structural terms and formed by breaching Grice's maxims and ignoring obvious assumptions understood from the context. Zhou (2009) studied Grice' Cooperative Maxims in oral English teaching and concluded that this principle and its maxims can explain the implications in communication. Observing the cooperative principle in teaching oral English can improve flexibility and accuracy of language communication which seems to be the ultimate aims of spoken language. Pratiwi (2008) studied the violation of Grice's Cooperative Principle in the movie Before Sunset. He concluded that cooperative principle was violated in two scenes of the movies and the implied meanings used by the speakers led to untruthful answers. Although the speaker violated the principle, the messages behind the utterances were got by the listeners. In fact, the conversation was still understandable.

Pan (2012) studied the linguistic structures involved in the process of verbal humor based on Grice's Cooperative Principle, and tried to discover the relation between the creation of humor and violation of Grice's principle and criticize the cooperative principle by focusing on the limitations of this principle. Cooperative Principle and its four maxims state that a successful and effective conversation requires honest and clear mutual communication in providing related and sufficient information for creating discourse. However, when an unrelated topic is provided and its denotative accurate meaning is challenged, primary factors creating humor are formed. In addition, ambiguous and exaggerating statements are also the main grounds of humor. Therefore, it can be concluded that violation of cooperative principle is closely related to the creation of humor. To understand and construe humor accurately, the denotative and pragmatic content is of significance and through which linguistic, communicative, and learning aspects between foreign cultures and languages can be recognized. On the other hand, metaphoric meaning is to be understood as well so that the meaning and intentions of the speaker are realized. The study of Grice's Cooperative Principle and its maxims help us to understand the deep meaning of humor. Schoolfield (2007) studied the Grice's Cooperative Principle in relativity and discourse. The results of this research indicate that violation of Grice's Principle stops when conversational cues inform the participants of conversation that irrational statements are better understood within a conventional framework. 


\section{GRICE'S COOPERATIVE PRINCIPLE}

The theoretical framework of this research is based on the Grice' Cooperative Principle. Grice introduced a set of rules which were expected in his opinion to be observed by the participants of a conversation. He formulated these rules in form of the conversational cooperative principle and stated, "Make your contribution such required, at the stage at which it occurs, by the accepted purpose, or direction of the talk exchange in which you are engaged" (Grice, 1975: 45).

Grice believes that a talk exchange will be managed successfully only if the participants bound themselves to the communication objectives. Accordingly, Grice's Cooperative Principle is reflected in form of its four conversational maxims which are unavoidable and cohesive. Any intentional and deliberate suspense or use of conversational maxims creates implications, which is understood by the listener based on cooperative principle. According to Grice, observing cooperative principle is a rational behavior since it guarantees that the listener can reach his/her objective. McHale argues that Grice wants to generalize his approach to conversation or directs it towards an ideal and logical attitude to the society of pragmatics. By contrast, McHale refrains from providing such a vast attitude to this issue. Conversation theory is always entangled in providing an irrational image of human interactions and it tries to set out special rules for the culture of conversation and talk exchange. For instance, Dell Hymes believes that Grice's approach to conversation is an ideal and indirect image of situation. Sandra Harris expresses that such an approach used by Grice is prescriptive and has excessive behavioral requirements. According to Grice identifies the cooperative principle as a superprinciple generalized from four conversational principles. These principles include:

Quality: do not say that for which you lack adequate evidence or you know it is false, A) do not say what we know to be false; B) do not say something for which you lack adequate evidence; therefore, lie, guess, and surmise are considered as the violation of quality maxim.

Quantity: Quantity means making our contribution as informative as is required; A) provide information as required, B) do not provide more information as required. Therefore, reticence and verbosity are considered violation of quantity maxim.

Relevance: Be relevant, that is talk about the related topic. If the speaker is not bound to the topic, the relevance maxim is violated.

Manner: Avoid obscurity and ambiguity of meaning; be brief, that is avoid unnecessary prolixity and talk in an orderly manner. A) avoid ambiguity, B) avoid unnecessary complications, C) talk in an orderly manner; Therefore, disordered and sarcastic expressions full of metaphors and descriptions are considered violation of the maxim of manner (Grice, 1975: 45).

\section{Data Analysis}

In this section, 50 ads of Hamshahri and Jame Jam Newspapers are studied in terms of Grice's Cooperative Principle. Because of high volume of data, five ads have been selected from each newspaper as samples.

\subsection{Detergent Ads: CLOTHES FALL IN LOVE (Jame Jam Newspaper)}

Quality: This ad violates the maxim of quality. Inanimate objects cannot fall in love. Therefore, this statement is false and may not happen in reality. In fact, this ad fails to reflect truth and thus violates the maxim of quality.

Quantity: This ad violates the maxim of quantity as well. The title of this ad deviates from the subject, and as it fails to address the main subject of the ad, it violates the maxim of quantity.

Manner: This ad violates the maxim of manner too. If this title does not belong to the advertisement of an article and it is considered as a normal statement, no ambiguity can be found in the title. Considering that this is an advertisement for an article, that is a detergent, the statement is highly ambiguous, and it is not clear what it means. Therefore, the title violates the maxim of manner.

Relevance: This ad violates the maxim of relevance. The topic introduced in the title of the ad is not related at all to the detergent powder and can never be related to such an issue. Thus, it violates the maxim of relevance too. 


\subsection{Bingo Plus Ad: BINGO CAKES, HEAD AND SHOULDERS ABOVE (Jame Jam Newspaper)}

Quality: This ad violates the maxim of quality. The Persian idiom "head and shoulders above" (literary: a head and neck above others) means being superior to someone and it is used only for human being. Hence, it is not used for inanimate objects and specifically for foodstuffs. This ad looks like an exaggerated slogan. In fact, there is no evidence or example of the claim expressed by this advertisement. Hence, it is a false statement. As this ad is not true, it violates the maxim of quality.

Quantity: This ad violates the maxim of quantity too. It lacks sufficient information and is too brief to clarify meaning. Therefore, it breaches the maximum of quantity.

Manner: This ad violates the maxim of manner, because its wording causes ambiguity and no clear meaning can be grasped by it. The words head and shoulders together with cakes make the meaning opaque and the intention of the ad may be understood ambiguously. That makes the ad violates the maxim of manner.

Relevance: This ad complies with the maxim of relevance. The advertisement is completely related to its subject. It talks about the article for which it advertises. No irrelevance can be understood from the title of the advertisement. Therefore, it complies with the maxim of relevance.

\subsection{Latifi Sporting Goods and Equipments: BRING THE GYM INTO YOUR HOME (Jame Jam Newspaper)}

Quality: This ad violates the maxim of quality. In the real world, it is impossible to bring a gym to your home. It is however possible to assign a part of your home to the gym, but it is not possible to bring the entire gym as it is into the home, where people live. This statement is false, and when we believe something is false, it is violation of the maxim of quality to express such a false statement. That is why we claim that the ad violates the maxim of quality.

Quantity: This ad violates the maxim of quantity. It is too short, and it seems that the topic is to be more explained. As a result, the maxim of quantity is violated.

Manner: This ad complies with the maxim of manner. This title is a clear declarative statement and no ambiguity or opacity is found in it. The statement is not too long to make the subject ambiguous. Therefore, the maxim of manner has not been violated.

Relevance: This ad complies with the maxim of relevance. The main topic introduced by the ad is about sport and gym equipment. That is the title of ad and subject of the ad are related. Thus, the maxim of relevance has been observed by this advertisement.

\subsection{Iran Khodro Advertisement about fakes auto parts: WELCOME DANGER (Jame Jam Newspaper)}

Quality: This ad violates the maxim of quality. In Persian, we welcome somebody not an inanimate object. For example, a person who has returned from a trip is welcome by somebody else. In this ad, the word welcome has been employed for the feeling of a person, and therefore, the statement is considered false. We cannot welcome danger which is an emotion. The maxim of quality has been thus violated by this advertisement.

Quantity: This ad violates the maxim of quantity. This ad is too short and compact. The reader may ask why and how we welcome danger. Such a briefness has caused the advertisement fails to express the main subject. Thus, the maxi of quantity has been violated.

Manner: This ad violates the maxim of manner too. It is ambiguous and causes the meaning to be opaque. The meaning of the word welcome is not clear in this advertisement. Welcoming danger may mean that we are happy to re-visit danger. On the other hand, it may mean that dangerous measures can cause by contrast serious dangers in our life. This advertisement causes ambiguity in meaning and therefore, violates the maxim of manner.

Relevance: This ad complies with the maxim of relevance. The main subject of the advertisement is about the use of fake parts and the ad is about the same issue. There are completely related to each other. Fake parts can cause dangers too. The advertisement is also about the danger caused by fake parts, and the relation is so that any use of nonstandard parts can cause danger. Therefore, the ad complies with the maxim of relevance. 
The Study of Grice Principle Application in Commercial Advertisements of Hamshahri and Jame Jam Newspapers

In the following table, 25 ads of Jame Jam Newspaper have been collected and studied in tabular form.

Table1. Classification of Compliance or Noncompliance of Jame Jam Newspaper Ads from Cooperative Principle

\begin{tabular}{|c|c|c|c|c|c|}
\hline \multirow[t]{3}{*}{ row } & \multirow[t]{3}{*}{ Ad Title } & \multicolumn{4}{|c|}{ Cooperative Principle } \\
\hline & & \multicolumn{4}{|c|}{ Compliance-Violation } \\
\hline & & Quality & Quantity & Manner & Relevance \\
\hline 1 & Tissot Watches: Beyond Time & $*$ & $*$ & $\sqrt{ }$ & $*$ \\
\hline 2 & $\begin{array}{l}\text { Hamrah-e Aval (First Operator) SIM Card: No One is } \\
\text { Alone }\end{array}$ & $*$ & $\checkmark$ & $*$ & * \\
\hline 3 & Detergent: Clothes Fall in Love & $*$ & $*$ & $*$ & $*$ \\
\hline 4 & Life Insurance: Aren't you really insured? & $\checkmark$ & $\sqrt{ }$ & $\checkmark$ & \\
\hline 5 & Tissot Watches: Time is under Your Control & $*$ & $\gamma$ & $y$ & $\checkmark$ \\
\hline 6 & $\begin{array}{l}\text { Mellat Insurance: Hand in Hand with the Nation } \\
\text { (Mellat) }\end{array}$ & $*$ & $*$ & $*$ & $*$ \\
\hline 7 & Carpet Center: Mr. Carpet & $*$ & $*$ & $*$ & \\
\hline 8 & $\begin{array}{l}\text { Razi Insurance: We are Golden because of your } \\
\text { satisfaction }\end{array}$ & $*$ & $*$ & $*$ & $\checkmark$ \\
\hline 9 & Oila Oil: Oila loves your heart & $*$ & $*$ & $\checkmark$ & $*$ \\
\hline 10 & Grad Clothing: New Year, Happy Friendship & $\checkmark$ & $*$ & $\checkmark$ & $*$ \\
\hline 11 & Pool: Smart Pool & $*$ & $*$ & $*$ & \\
\hline 12 & Latifi Sport Equipment: Bring the Gym to your Home & $*$ & $*$ & $\checkmark$ & $\checkmark$ \\
\hline 13 & Healthy market: Be healthy & $\checkmark$ & $*$ & $\checkmark$ & $\checkmark$ \\
\hline 14 & Rightell cell: day and night of world is in your hand & $*$ & $*$ & $\checkmark$ & $*$ \\
\hline 15 & Irancell cell: we are star with you & * & $*$ & $*$ & $*$ \\
\hline 16 & Gardeshgari bank: take your card & $\checkmark$ & $\checkmark$ & & $\checkmark$ \\
\hline 17 & Chitgar complex residential: be neighbor with nature & $*$ & $*$ & $\checkmark$ & $*$ \\
\hline 18 & Iranautomobile: going to meet of danger & $*$ & $*$ & $*$ & $\checkmark$ \\
\hline 19 & Siv soap: behind all smile is a reason & $\checkmark$ & $\checkmark$ & $\checkmark$ & \\
\hline 20 & $\begin{array}{l}\text { Parskhazar equipment of home: parskhazar equipment } \\
\text { for a live }\end{array}$ & & & & \\
\hline 21 & Hamraheaval cell: accessible dreams & $\checkmark$ & $\checkmark$ & $\checkmark$ & \\
\hline 22 & Parsian insurance: a world of calmness & & & & $\checkmark$ \\
\hline 23 & $\begin{array}{l}\text { Pasargad bank: all we have done, was for God } \\
\text { kindness }\end{array}$ & $\checkmark$ & $\checkmark$ & $\checkmark$ & \\
\hline 24 & Hasti rice: production of new birth & $*$ & $*$ & $*$ & $\checkmark$ \\
\hline 25 & $\begin{array}{l}\text { Bingopluse biscuit: bingopluse biscuit is stand head } \\
\text { of other }\end{array}$ & $*$ & $*$ & $*$ & \\
\hline
\end{tabular}

Follow: $\$ Broken:*

\subsection{Advertisement of Iran Insurance Company: A YOUNG SEEDLING WITH OLD ROOTS (Hamshahri Newspaper)}

Quality: This ad violates the maxim of quality. The statement of the ad is false, since the young seedling cultured recently and grow up gradually has you roots too. A young seedling cannot have an old root. This ad lacks truth and honesty, and no referent can be found in the real world for such a claim. It is exaggerating and therefore, it violates the maxim of quality.

Quantity: This ad violates the maxim of quantity, because it is too short. In other words, its shortcoming in expressing the subject of ad makes it unclear. It needs to be explained.

Manner: This ad violates the maxim of relevance. A young seedling with old roots causes ambiguity for the reader. The message this advertisement is trying to transfer is ambiguous and confusing and its meaning is not clear. In this ad, the opacity of meaning is obvious and therefore, it violates the maxim of manner.

Relevance: This ad violates the maxim of relevance. The ad is not related to the ad in no way. The subject of the ad is about insurance, and the ad is about seedling and roots which are unrelated to each other. Therefore, we can claim that the maxim of relevance has been violated in this advertisement. As a result, due to this irrelevance, we can claim that the ad violates the maxim of relevance. 
In this ad, all four maxims have been violated.

\subsection{Dentistry Ad: TURNING ON A CIGARETTE TURNS OFF A SMILE (Hamshahri Newspaper)}

Quality: This ad violates the maxim of quality, because it is not true and is with exaggeration. In the real world, especially in Persian, the word turn on is not used for cigarette. In addition, smile is an emotional reaction of human being and it cannot be turned off. This ad is not true and is not expressed with honesty, because we cannot find any referent for such a referring expressing in the real world. Therefore, the maxim of quality is violated.

Quantity: This ad violates the maxim of quantity. The ad is just like a slogan and is too short to express the main subject. It requires more explanations for expressing the complete meaning. Hence, the maxim of quality has been violated in this advertisement.

Manner: This ad violates the maxim of manner. In this ad, the superficial meaning of the words is not of importance. The whole statement of the ad is a metaphor. The words turn on and turn off mean smoking and not laughing respectively. This metaphor may cause ambiguity and its meaning is opaque. As a result, this ad violates the maxim of manner.

Relevance: This ad complies with the maxim of relevance. Although this statement uses a figurative language in which turn on is the antonym of turn off and metaphor, the relevance can be seen between the ad and its subject. Cigarette smokers have no bright and white teeth; therefore, they have no beautiful smile. Such a smile is like being turned off as it was mentioned in the advertisement. So, the maxim of relevance has not been violated in the advertisement.

\subsection{Ad of Golrang MultiVita Shampoo: Complete Food of Hair (Hamshahri Newspaper)}

Quality: This ad violates the maxim of quality. Shampoo is not complete food of hair. It is a sort of exaggeration and it is therefore false and has not been expressed with honesty. In the real world, shampoo is not complete food for human hair and any shampoo is not necessarily suitable for the hair of each human. Therefore, this advertisement is therefore false and the maxim of quality has been violated.

Quantity: This ad violates the maxim of quantity, and is in form of a very short declarative statement. The issue has not been explained adequately and is too short that violates the maxim of quantity.

Manner: This ad complies with the maxim of manner, as the concept and meaning of the ad is clear and no ambiguity can be seen in the advertisement. Therefore, the maxim of manner has not been violated.

Relevance: This ad complies with the maxim of relevance. The subject of the ad is completely related with the statement of the advertisement. The statement of the ad is exactly about its subject. Therefore, the maxim of relevance complies with the maxim of relevance.

\subsection{Tanzib Sport Equipment Ad: GET SLIM AFTER THREE WHISTLES! (Hamshahri Newspaper)}

Quality: This ad violate the maxim of quality. Three whistles in this ad is mean "in a very short time". But this claim is not true because get slim by whatever in very short time is impossible. So, this adlacks truth and honesty, and no referent can be found in the real world for such a claim. It is exaggerating and therefore, it violates the maxim of quality.

Quantity: This ad complies with the maxim of quantity. This issue has been wxplained adequately and it is not too short or too long. So, we can see the maxim of quantity in this ad.

Manner: This ad complies with the maxim of manner, as the concept and meaning of the ad is clear and no ambiguity can be seen in the advertisement. Therefore, the maxim of manner has not been violated.

Relevance: This ad complies with the maxim of relevance. The subject of the ad is completely related with the statement of the advertisement. The statement of the ad is exactly about its subject. Therefore, the maxim of relevance complies with the maxim of relevance. 
The Study of Grice Principle Application in Commercial Advertisements of Hamshahri and Jame Jam Newspapers

Table2. Classification of following and broken of Gricean cooperative principle in Hamshahri commercial advertisement

\begin{tabular}{|c|c|c|c|c|c|}
\hline \multirow[t]{3}{*}{ row } & \multirow[t]{3}{*}{ Ad Title } & \multicolumn{4}{|c|}{ Cooperative Principle } \\
\hline & & \multicolumn{4}{|c|}{ Compliance-Violation } \\
\hline & & Quality & Quantity & Manner & Relevance \\
\hline 1 & LG electric equipment: Nowruz is your day. & $*$ & $*$ & $\checkmark$ & $*$ \\
\hline 2 & Panasonic juicing: last and last drop! & $\checkmark$ & $*$ & & $*$ \\
\hline 3 & Travel agency: go trip so easy! & $\gamma$ & $\checkmark$ & $y$ & $\checkmark$ \\
\hline 4 & LG TV: Future generation of TV & $*$ & $*$ & $*$ & $\checkmark$ \\
\hline 5 & Young seedling with old roots! & $*$ & $*$ & $*$ & $*$ \\
\hline 6 & Hmrahe aval cell: rain of winter plan! & $*$ & $\checkmark$ & $\checkmark$ & $*$ \\
\hline 7 & Eghtesad e Novin bank: we are all with you! & $\checkmark$ & $\checkmark$ & $\checkmark$ & $*$ \\
\hline 8 & Dentist office: Cigarette lights, slience of smile & $*$ & $*$ & $*$ & $*$ \\
\hline 9 & Barfab refrigerator & $*$ & $*$ & $\checkmark$ & * \\
\hline 10 & $\begin{array}{l}\text { Fuman chemistry: Safe trip with Fuman chemistry } \\
\text { engine oil }\end{array}$ & $*$ & & * & \\
\hline 11 & $\begin{array}{l}\text { Eghtesad Novin's internet Bank: your work desk is } \\
\text { always with you }\end{array}$ & * & $\checkmark$ & $*$ & $*$ \\
\hline 12 & Azim Car company: a new year! A new car! & $*$ & $*$ & $*$ & \\
\hline 13 & Eghtesad Novin's doorway bank: connected in a jiffy! & $*$ & $*$ & $*$ & \\
\hline 14 & Sadaad data office: more transaction! More score! & * & * & $*$ & $\checkmark$ \\
\hline 15 & Ave hand wash foam: experience of life in sea & $\checkmark$ & $\checkmark$ & $\checkmark$ & $*$ \\
\hline 16 & $\begin{array}{l}\text { Tanzib Sport Equipment: GET SLIM AFTER THREE } \\
\text { WHISTLES! }\end{array}$ & $*$ & $\checkmark$ & $\checkmark$ & $\checkmark$ \\
\hline 17 & Iranian MELLI bank: all are winner! & $*$ & $\checkmark$ & $\checkmark$ & $\checkmark$ \\
\hline 18 & Golrang MultiVita Shampoo: Complete Food of Hair & $*$ & $*$ & $\checkmark$ & \\
\hline 19 & Eghtesade Novin's insurance bank: & $\checkmark$ & $\checkmark$ & $\checkmark$ & \\
\hline 20 & $\begin{array}{l}\text { Panasonic vacuum cleaner: broom with three head, } \\
\text { easy magic! }\end{array}$ & $*$ & $\checkmark$ & $*$ & $\checkmark$ \\
\hline 21 & Maxim clothes: clothes of today and future & $*$ & $*$ & $*$ & $\checkmark$ \\
\hline 22 & $\begin{array}{l}\text { Nik kaalaa home equipment: have nice year better } \\
\text { than the past years! }\end{array}$ & $*$ & $*$ & $*$ & $*$ \\
\hline 23 & Qatar airline: a lotf of trip in Nowruz by Qatar airline & $\checkmark$ & $\checkmark$ & $\checkmark$ & $\checkmark$ \\
\hline 24 & Ilia Metal: have a nice year & $*$ & $*$ & $\checkmark$ & $*$ \\
\hline 25 & $\begin{array}{l}\text { Damaavand mineral water: damaavand is longer than } \\
\text { always! }\end{array}$ & $*$ & $*$ & $*$ & $*$ \\
\hline
\end{tabular}

\section{Follow: $\$ Broken: *}

In this part we have graphs of distribution of Gricean cooperative principle in Jame Jam and Hamshahri newspaper:

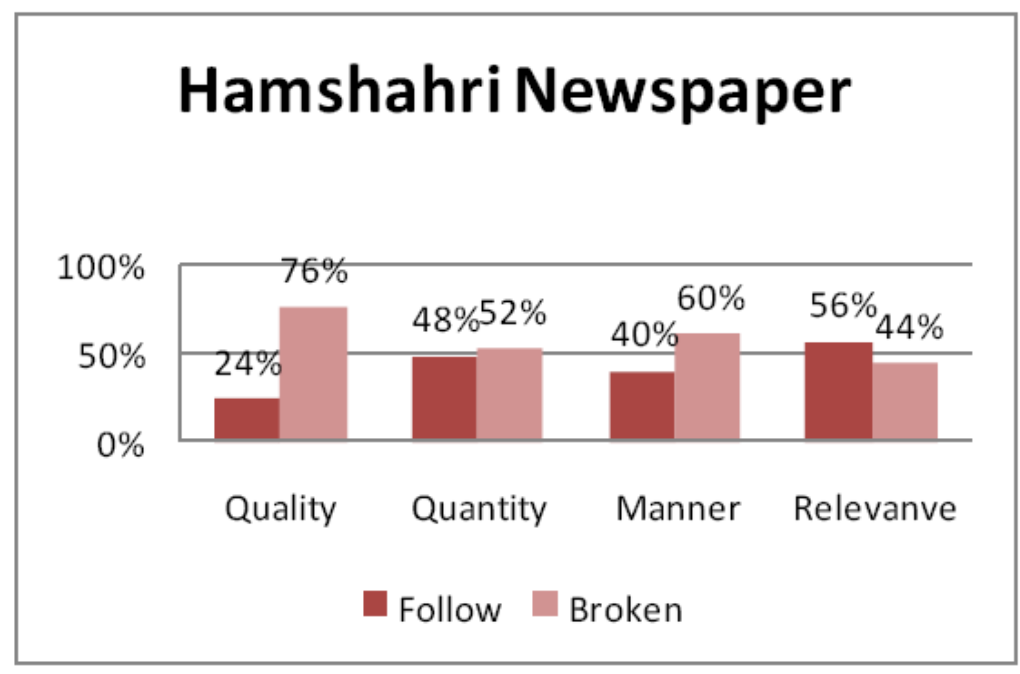

Figure1. Percent of following and broken of Gricean cooperative principle in Hmashahri newspaper 


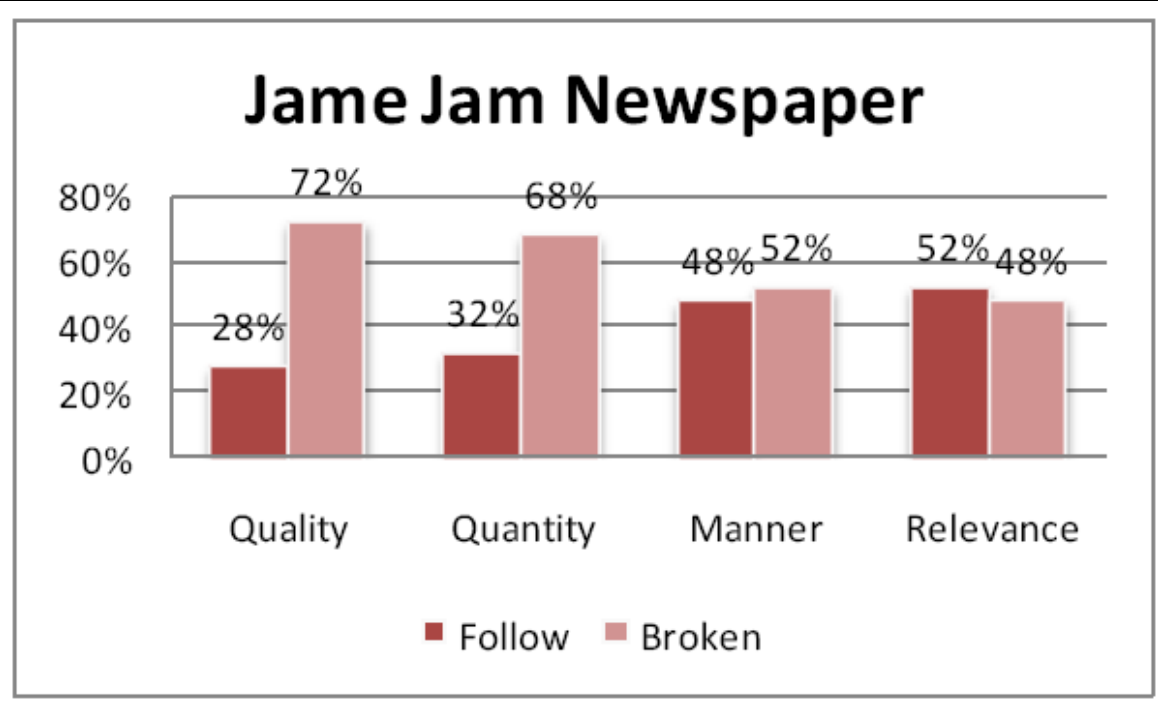

Figure2. Percent of following and broken of Gricean cooperative principle in Jame Jam newspaper

Here we can see the comparative distribution graph of following and broken of Gricean cooperative principle in both Jame Jam and Hamshahri newspaper:

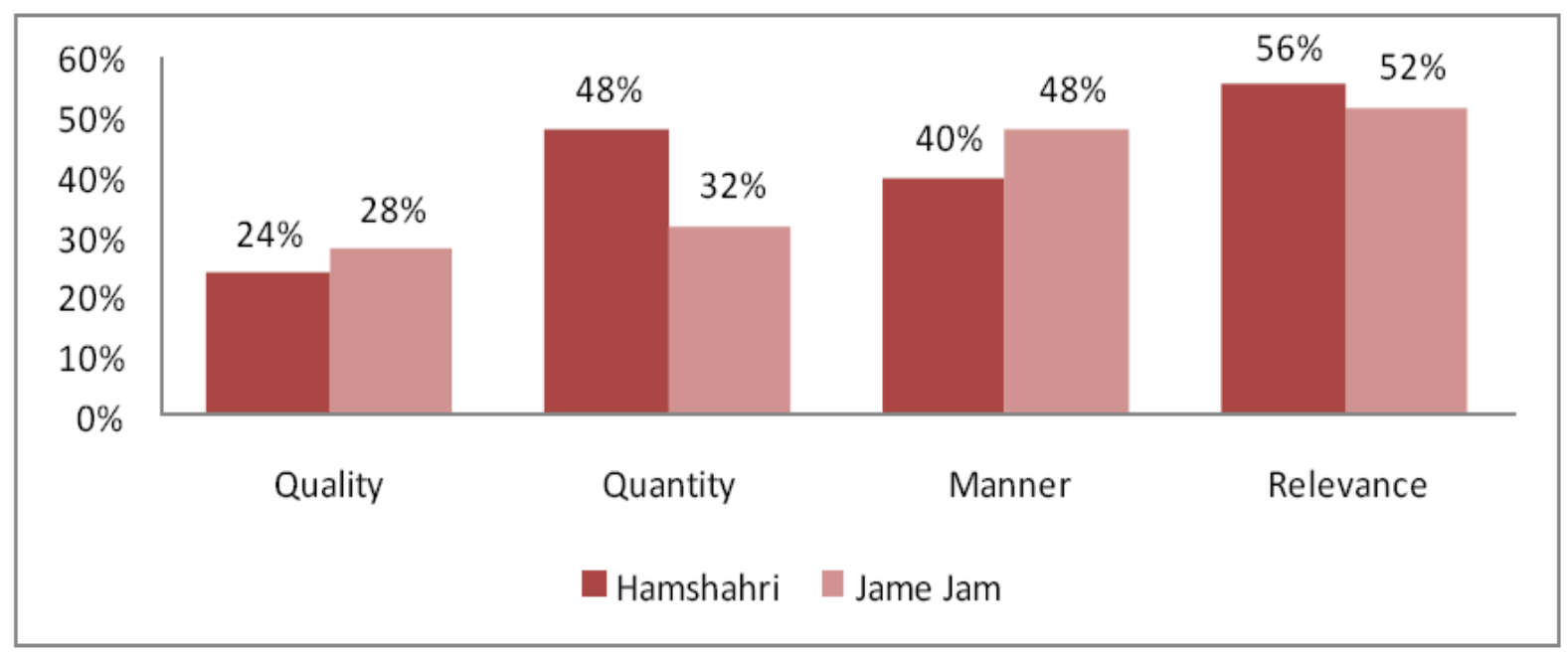

Figure3. Comparative distribution of Gricean cooperative principle in both Jame Jam and Hamshahri newspaper

\section{RESULTS AND DISCUSSION}

Research findings and statistics show that on average $44 \%$ and $60 \%$ (in Hamshahri Newspaper) and $40 \%$ and $60 \%$ ( in Jame Jam Newspaper) have been respectively observed and disobeyed, while in total the amounts in both papers have reached $42 \%$ and $58 \%$ respectively. Of these recorded statistics, the most disobeyed maxim is the maxim of quality (74\%), whereas the least observed is the maxi of relevance $(56 \%$. Research results show that between the two papers, the maxim of quality has suffered the highest flouting; the rest of the maxim are respectively followed by the maxi of manner, the maxim of quantity, and the maxim of relevance. With regard to the maxim of quality, it can be stated that what most often is seen throughout business or commercial advertisement is the stuff disbelieved by the narrator and no document or evidence can have it proved. In time, this would lead to the loss of meaning in words i.e. words or vocabularies would be meaningless. As a result, the narrator would have no choice but to resort to using improper, emphatic and irrelevant lexicon. Indeed, the advertisers are meaning to force their audience (the trust of whom have been breached) into believing the descriptions associated with their products or conveyed message. One of the effective tricks is embarking on contextually displaced vocabularies by which deeper meaning is carried. For instance, in Jame Jam's $7^{\text {th }}$ edition article (Mr. Carpet), index Mr. originally used for a male person was in front of the non-living object, carpet. Had index Mr. indeed carried its own meaning, it would have been unacceptable and redundant to put it in front of this non-living-object. Nevertheless, index Mr. carries a deeper meaning. 
Even though it' $\mathrm{d}$ been contextually displaced, the trick was professionally developed and attracted the audience attention. Another could be Jame Jam Newspapers' $14^{\text {th }}$ edition article (Raitel Communication Services: Universal day \& night belongs to you). Here, the writer used exaggeration conveying the message of mankind power and authority. This article has no document or evidence to prove that its descriptions would whether fit the real world or not. That's how the maxim of quality has been flouted. This approach, though, left an impression on audience mind; the article implies the fact that not only does this communication company provide beyond-expectation services but the clients have full authority over their needs and favorite choices and, as a results, getting clients to put their confidence and trust in them. As far as the maxim of quantity is concerned, it can be said that some of the advertising phrases and expressions are short and brief e.g. in Jame Jam's 1th edition article (Beyond time), it's actually a very small advertisement in which the maxim of quantity has been breached. However, this breach of maxim conveys a message without which it'd be impossible. Persian speakers who are living in a context where everyone speaks Persian and can figure out proverbs, sayings and short expressions, would create an image in their minds that the advertised watch is so unique and quartz and can provide other options and facilities. Thus the message is worked out clearly and the impression is left on mind. Indeed, although the maxim of quality (as one of the most important maxims of CP) has been flouted, given its shortness and brevity, the audience can easily figure out the message.

With regard to the maxim of relevance, it can be mentioned that flouting this maxim could make the message content even more attractive; otherwise, it may not even leave an impression i.e. once the main content and the article aren't relevant, the audience would find it way more attractive. In fact, it could be stated that in advertising, irrelevant talk is one of the common was of achieving goals. As an example, in Hamshahri's $15^{\text {th }}$ edition article (the experience of world behind the seas), what could be the possible connection between detergent and the world behind seas? Despite the fact that the world behind seas is one of the many places on earth, detergent has been made by human being and no connection can be drawn between them, a sense of strong connection is being conveyed that it would be impossible without breaching the relevance maxim of CP. As far as the maxim of manner is concerned, it can be mentioned that common manners used in advertisement are extremely diverse. Making an article or news complicated and embarking on ambiguities have been widely applied as a successful strategy. For instance, in Hamshahri's $8^{\text {th }}$ edition article (turning a cigarette on would turn off an smile), using a figure of speech such as metaphor can leave a certain impression on audience to be fascinated about acquiring more news and information. As soon as the mind is occupied with an effort to figure out the apparently complicated message developed by the writer, it would have the audience to get their mind and thought engaged to the advertised item and leave a strong image and impression on mind along with memory. In other words, such complication would be so effective in catching the audience attention and stopping by to check it out outside. In Hamshahri's $18^{\text {th }}$ edition article (Embracing Danger) for example, in order to persuade audience for buying genuine parts and avoiding fake ones, not only is it clearly referred to this issue or problem, but it's paradoxically implied and said: Embracing Danger.

\section{Conclusion}

In this study, the application scale of CP in articles put in the two Persian- language news papers, Hamshahri \& Jame Jam has been examined. The research results and analysis demonstrate that CP application is more followed by Hamshahri than Jame Jam newspaper. Research findings regarding the considerable differences in percentage amounts is associated with the fact that in spite of the high importance of Grices' CP in advertising arena, for the two newspapers (Hamshahri and Jame Jam), this rule is not prioritized clearly and accurately by the writers and reporters, and its function is lower than the expectations. Furthermore, the acquired results is a testimony to the fact that despite its significance, cooperation principals are not on the writer and reporters' priority list once it comes to stating their mind and intention on the paper.

Reporters and writers engaged in commercial advertisement are intentionally flouting the CP in their own interest. As it was already discussed, breaching the CP maxims refers to the fact that the speaker is already knowing the truth or reality about which the listener doesn't and is only trying to express the words in their literal manner. In other words, the speaker is stating insufficient, invalid and irrelevant and ambiguous news and information by which the listener is being mislead. In order to 
attract audience attention, in most of the commercial advertisements , the message carrier is breaking the rules of $\mathrm{CP}$ which means the expressions and phrases expressed are attractive, insincere, unreal, slogan and dream-like. At this very moment, although the audience might not have sufficient information with regard to the main topic, content and the article in question and it could by the first time ever, playing with the words and irrelevancy would get the audience impressed being persuaded to purchase and try out the item at least once in a lifetime. This would mean the speaker's win over the clients. In Hamshahri Newspaper, the highest observed maxim is relevance and the rest is respectively followed by quantity, manner and quality. Also the findings shows that in Jame Jam Newspaper, the maxim order from the most to the least is followed by relevance, manner, quantity and quality. Observing the rules of $\mathrm{CP}$ would make leave the communications and conversations ideal, appropriate and systematic. In other word, in stances in which all four maxims are being observed are undoubtedly the most valid and systematic. However, observations and examinations show that even if these four maxis aren't observed in everyday communications and conversations, still the audience can figure the topic in question out and work it out i.e. not-observing the maxims of cooperation wouldn't leave the audience in darkness and would definitely bring the message home to the audience.

\section{REFERENCES}

[1] Zhu, M. (2009). "Cooperative principle in oral English teaching", School of foreign language, Zhejiang Gongshang University.

[2] Schoolfield, M. (2007), "Rationality and conversation" a thesis on Grice's theory of conversation", university of Edinburgh

[3] Pratiwi, K. (2008). "The study of the flouting of Grice's cooperative principle in the movie entitled before sunset" Petra Christian university.

[4] Pan, W. (2012). "Linguistic basis of humor in uses of Grice' cooperative principle", National Research Center for Foreign Language Education, Beijing Foreign Studies University.

[5] Grice, H. p. (1975), "Logic and Conversation", Reprinted from syntax and semantic 3, with permission from Elsevier (2004)

[6] Grice, H. P. (1989), Studies in the way of words, Cambridge, MA: Harvard University Press.

[7] Kheirabadi, H. (2013), "Role of flouting of Gricean cooperative principle in the new generation of Iranian jokes", literature and language, lingual inquiry, No. 15.

[8] Ahmadian, M. and Mostofi, K. (2011)," Study in elements of intent and fear in the characters of the play "Janitor" written by Harold Pinter, in terms of Gricean cooperative principle, Publication of literary though, second period, No. 35.

\section{AUTHORS' BIOGRAPHY}

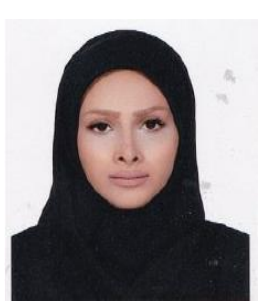

Anis Ebrahimi, was born in Tehran in 1989. She is BS of English Translation at Takestan Branch, Islamic Azad University, in 2014. She is now, MA student of linguistics, at Central Tehran, Islamic Azad University. She has published an article in Linguistics, in 2015. She is member of Young Researcher society and linguistics society.

Foroogh Kazemi, is assistant professor of linguistics department in Central Tehran Branch, Islamic Azad University in Iran. She has taught linguistics, Persian and English at Central Tehran Branch, Imam Khomeini International University and Science and Research Branch. Dr. Kazemi has published many articles in linguistics and has been advisor, reader and referee of many linguistic MA theses and judge of articles in journal of linguistics. Her areas of interest are functional linguistics, sociolinguistics, typology and discourse analysis, She is the head of linguistics department and a member of research council in Central Tehran Branch, Islamic Azad University. 